(C) 2018 International Journal of Nursing and Midwifery Science(IJNMS)

This is an Open Access article distributed under the terms of the Creative CommonsAttribution 4.0 International License which permits unrestricted noncommercial use, distribution, and reproduction in any medium, provided the original work is properly cited.

\title{
EFFECT OF EARLY MOBILIZATION TO URINE RETENTION EVENT POST HERNIOTOMY OPERATION IN RSUD PROF DR SOEKANDAR MOJOSARI
}

\author{
Lutfi Wahyuni ${ }^{1}$, Binarti Dwi Wahyuningsih ${ }^{2}$ \\ School of health Bina Sehat PPNI Mojokerto Regency East Java Indonesia \\ Email correspondence: ltf.hidayat@gmail.com
}

\section{ABSTRACT}

Keywords

A Hernia is a problem that can be found in the case of surgery and became the most cases of surgery after appendicitis. Emergency cases can occur if a hernia is sedentary where there has been a blockage in the food channel which eventually the blood vessels caught should be surgery called herniotomy. Mobilization is an independent action for a nurse in performing nursing care in post-surgical patients to prevent the occurrence of urinary retention that does not cost. Most of the patients still have concerns that the body is moved to a certain postoperative position will affect the still-unhealed surgical wound that has just been done. Though not entirely this problem needs to be feared, even just about any type of surgery requires mobilization or movement of the body as early as possible provided that pain can be retained and the balance of the body is no longer a nuisance This study aims to identify the incidence of urinary retention in postoperative herniotomy patients after early mobilestation. The design used in this study was pre-experimental with a one-shot case study design. In this study, given the early mobilization intervention in patients post herniotomy and then observed whether there is urinary retention or not. The population in this study were all patients who had undergone herniotomy surgery at RSUD Soekandar Mojosari in February of 2017 as many as 30 respondents. Samples were taken by consecutive sampling technique. The independent variable is early mobilization. While the dependent variable is the incidence of urinary retention. The instrument uses an observation sheet containing special data and the presence or absence of a urinary retention event. The result of the research showed that in stage 1 of 30 respondents can be seen that the decrease in the number of respondents who have urinary retention at stage 1 (first 6 hours post operation) there are 24 respondents (96\%) who experience urine retention, at stage 2 (6-12 hours post operation) to 9 respondents (30\%) further in phase 3 (12-18 hours post operation) decreased to 2 respondents $(6,6 \%)$ and at stage 4 (18-24 hours post operation) no respondent had urinary retention. There is an effect of early mobilization on the incidence of urinary retention with different responses in each respondent. Early mobilization is influenced by physical factors, emotions and age, and developmental status. 


\section{PRELIMINARY}

Emergency cases may occur if a hernia is sedentary where there has been a blockage in the food duct that eventually the blood vessels caught should be surgically called herniotomy (Adwan, 2013). This will certainly reduce hospitalization time, reduce financing and also can reduce psychic stress. At the beginning of the physical movement can be done on the bed by moving the hands and feet that can be bent or straightened, contracting the muscles in a state of static and dynamic as well as moving other bodies, tilted to the left or right (Fatmah, 2010) Many problems arise from surgery and the risk of anesthesia (spinal anesthesia), including the incidence of urinary retention (Brunner \&Suddarth, 2006) World Health Organization (WHO) hernia incidence during 2010 in Indonesia was 32.9\% or about 78.2 million inhabitants (Vera Anik A., 2014). A hernia is the most surgical case in RSUD Soekandar Mojosari.

The number of postoperative hernia cases in 2014 was 229 cases, in 2015 as many as 249 cases, whereas until June of 2016 there were 106 cases (Medical Record, 2016). Urinary retention may occur due to urethral obstruction, surgical trauma, changes in sensory and bladder motor neuronal stimulation, drug side effects and anxiety (Potter, Patricia A \& Perry, 2007). Narcotic analgesics and anesthetics can slow the rate of glomerular filtration and reduce urine output. Spinal anesthesia primarily poses a risk of urinary retention, because as a result of this anesthesia, the client is unable to sense the need for urination and the possibility of bladder muscles and sphincter muscles are also unable to respond to the urge to urinate. Normally within 6 - 8 hours after anesthesia, the patient will get voluntary control of voiding function, depending on the type of surgery(Potter, Patricia A \& Perry, 2007). Some preventive measures of urinary retention after spinal anesthesia include limiting fluid intake, early mobilization, warm suprapubic compresses, and the use of short-acting spinal anesthesia (Akhrita, 2011). spinal anesthesia (Akhrita, 2011). Mobilization is an independent action for a nurse in performing nursing care in post-surgical patients to prevent the occurrence of urinary retention that does not cost. Most of the patients still have concerns that the body is moved to a certain postoperative position will affect the still-unhealed surgical wound that has just been done. Though not entirely this problem needs to be feared, even just about any type of surgery requires mobilization or movement of the body as early as possible provided that pain can be retained and the balance of the body is no longer a nuisance unhealed surgical wound that has just been done. Though not entirely this problem needs to be feared, even just about any type of surgery requires mobilization or movement of the body as early as possible provided that pain can be retained and the balance of the body is no longer a nuisance (Brunner \&Suddarth, 2006). Movements in the recovery period will accelerate the attainment of conditions such as pre-surgery. This will certainly reduce hospitalization time, reduce financing and also can reduce psychic stress. At the beginning of the physical movement can be done on the bed by moving the hands and feet that can be bent or straightened, contracting the muscles in a state of static and dynamic as well as moving other bodies, tilted to the left or right (Fatmah, 2010).

Based on the above phenomenon, the authors are interested to examine the "Influence of early mobilization of the incidence of urinary retention in patients post herniotomy in RSUD Soekandar Mojosari

\section{RESEARCH METHODS}

The design used in this study was preexperimental with a one-shot case study design (Arikunto, 2006). In this study, given the early mobilization intervention in patients post herniotomy and then observed whether there is urinary retention or not. The population in this study were all patients who had undergone herniotomy surgery at RSUD Soekandar Mojosari in February of 2017 as many as 30 respondents. Samples were taken by consecutive sampling technique. The independent variable is early mobilization. While the dependent variable 
is the incidence of urinary retention. The instrument uses an observation sheet containing special data and the presence or absence of a urinary retention event. Data analysis using descriptive analysis (Arikunto, 2006).

\section{RESEARCH RESULT}

\section{General data}

1.Table 1 Frequency Distribution of Respondents by Age

\begin{tabular}{lclc}
\hline N0 & \multicolumn{1}{c}{ Age } & F & \multicolumn{1}{c}{$\%$} \\
\hline 1 & $<26$ Years & 3 & $10 \%$ \\
\hline 2 & $26-35$ Years & 5 & $16 \%$ \\
\hline 3 & $36-45$ Years & 8 & $24 \%$ \\
\hline 4 & 46-56 Years & 6 & $20 \%$ \\
\hline 5 & $>$ 56 Years 3 & 10 & $30 \%$ \\
\hline & & 30 & $100 \%$ \\
\hline
\end{tabular}

According to table 1, almost half of the respondents were aged between 46-56 years old and $>56$ years, each of them was 6 respondents $(30 \%)$.

2.Table 2 Frequency Distribution of Respondents by Sex

\begin{tabular}{llll}
\hline N0 & Gender & F & \% \\
\hline 1 & Men & 26 & $86 \%$ \\
\hline 2 & Women & 4 & $14 \%$ \\
\hline & & 30 & $100 \%$ \\
\hline
\end{tabular}

According to table 2 shows almost all respondents of the male sex is 21 respondents $(86 \%)$.

3.Table 3 Frequency Distribution of Respondents by Education

\begin{tabular}{llll}
\hline No & \multicolumn{1}{c}{ Education } & \multicolumn{1}{c}{ F } & \% \\
\hline 1 & Basic (SD-SMP) & 20 & $66 \%$ \\
\hline 2 & $\begin{array}{l}\text { Medium (high } \\
\text { school) }\end{array}$ & 10 & $34 \%$ \\
\hline 3 & High /Academy & 0 & $0 \%$ \\
\hline$\quad$ Total & 30 & $100 \%$ \\
\hline
\end{tabular}

According to table 3 shows most of the respondents are primary education graduates (SD-SMP) that is as many as 15 respondents $(60 \%)$.

4.Table 4 Frequency Distribution of Respondents by Occupation

\begin{tabular}{llll} 
No & Work & F & $\%$ \\
\hline
\end{tabular}

\begin{tabular}{llll}
\hline 1 & Working & 20 & $66 \%$ \\
\hline 2 & $\begin{array}{l}\text { Not } \\
\text { Working }\end{array}$ & 10 & $34 \%$ \\
& & 30 & $100 \%$ \\
\hline
\end{tabular}

According to table 4 shows most respondents are respondents working as many as 15 respondents $(60 \%)$.

5.Table 5 Distribution Frequency of the incidence of urinary retention in postoperative herniotomy patients

\begin{tabular}{llllll}
\hline $\begin{array}{l}\text { N } \\
\text { o }\end{array}$ & $\begin{array}{l}\text { Stag } \\
\text { e }\end{array}$ & $\begin{array}{l}\text { Retenti } \\
\text { on }\end{array}$ & $\begin{array}{l}\text { No } \\
\text { Retenti } \\
\text { on }\end{array}$ & F & $\%$ \\
\hline 1 & Stag & 29 & 1 & 3 & 100 \\
& e I & & & 0 & $\%$ \\
\hline 2 & Stag & 9 & 21 & 3 & 100 \\
& e II & & & 0 & $\%$ \\
\hline 3 & Stag & 2 & 28 & 3 & 100 \\
& e III & & & 0 & $\%$ \\
\hline 4 & Stag & 0 & 30 & 3 & 100 \\
& e IV & & & 0 & $\%$ \\
\hline
\end{tabular}

Stage I: first 6 hours post op

Stage II: 6-12 hours post op

Stage III: 12-18hours post op

Stage IV: 18-24 hours post op

From table 5 above it can be seen that the decrease in the number of respondents who have urinary retention at stage 1 (first 6 hours post operation) there are 24 respondents $(96 \%)$ who experience urine retention, at stage 2 (6-12 hours post operation) to 9 respondents (30\%) further in phase 3 (12-18 hours post operation) decreased to 2 respondents $(6,6 \%)$ and at stage 4 (18-24 hours post operation) no respondent had urinary retention.

\section{DISCUSSION}

Based on Table 5 in Phase 1 exercises (6 hours after surgery), 29 patients (96\%) had urinary retention while 1 patient (4\%) had no urinary retention. According to (Tamer, 2009) suggests one of the factors that affect early mobilization is a physical factor. Physical is the posture, health (healthy or sick), the integrity of the body, the functioning of a person's organs (Efendi, 2013). The physical state of a weak person will directly affect the mobilization. This 
will limit the movement from lack of energy in the body. According to the assumptions of patients who have recently undergone surgery, the patient's physical condition has not recovered as in previous circumstances. This can make the patient feel reluctant to mobilize, other than that the perceived pain also makes the patient feel weak and just want to lie in bed and worried the stitches will tear and make the wound will be long healed. While one respondent did not experience urinary retention because it was able to withstand pain and mobilization according to the guidance that has been taught.

In stage 2 (6-12 hours post operation), respondents who experienced urine retention decreased to 9 people (30\%) while 21 people (70\%) were able to urinate.

According to (Tamer, 2009). One of the factors that can influence early mobilization is an emotional factor. Emotion is a unity of physiological reactions in man to deal with stimuli or stimuli that exist. People who are depressed, worried or anxious often cannot stand the activity so that more easily tired because of energized large enough in fear and anxiety so patients experience physical fatigue and emotion. The injury is also a stressor for someone who is hospitalized. Feelings experienced by postoperative patients against surgical wounds that have not healed will cause fear to mobilize. The relationship between pain and fear is complex. Feelings of fear often increase the perception of pain but pain can also cause fear. The pain stimulus activates parts of the limbic system that are believed to control one's emotions especially fear(Potter, Patricia A \& Perry, 2007). At this stage, there are 7 respondents who still experience urine retention. According to the researcher's assumption, the respondents are still afraid to move according to the mobilization stage that has been taught so that the fear becomes an obstacle for them to do mobilization which further affects the recovery of body systems including urban system.

In stage 3 (12-18 hours post operation) there are 2 respondents $(6,6 \%)$ who still experience urine retention. The respondent is over 60 years old. According to (Akhrita, 2011)early mobilization is also influenced by Age factor and Development Status. There is a difference in mobility ability at different age levels. This is because of the ability or maturity of the function of the motion device in line with the development of age. According to the World Health Organization (WHO) age 60 years and above including the elderly category. Groups that are categorized elderly will occur a process called aging process or the aging process.

The aging process is a life cycle that is marked by the steps of decreasing the various functions of organs. This is due to the increasing age that changes in the structure and function of cells, tissues, and organ systems (Vera Anik, 2014). These changes generally affect the deterioration of physical and psychological health that will ultimately affect the economic and social elderly. So, in general, will affect the activity of daily living (Fatmah, 2010). The problems that arise in the elderly can be caused due to physiological changes that occur in the body including the urinary system. In elderly vesica urinary bladder, muscles become weak, capacity decreases to $200 \mathrm{ml}$ or causes increase frequency, increase in residual volume, weakening of bladder muscle causing imperfect discharge and causing chronic urine retention (Tamer, 2009) In the opinion of the researchers, both respondents who still experienced urinary retention occurred due to age factor due to aging process where at that age there was a decrease in physical condition that made more respondents lying in bed and reluctant to mobilization as well as the decreasing function of body systems including urinary system which causes difficulties to urinate.

\section{CONCLUSION}

There is an effect of early mobilization on the incidence of urinary retention with different responses in each respondent.

\section{REFERENCE}

Adwan, Q. \&. (2013). Liver Disease, Stomach, Intestine And Hemorrhoid. 
Yogyakarta: Nuha Medika.

Akhrita, Z. (2011). Effect of Early

Mobilization on Bladder Recovery of

Patients With Spinal Anesthesia.

Retrieved from

www.repository.usu.ac.id

Arikunto. (2006). Research Procedures

Approach Practice. Jakarta: Rineka

Cipta.

Brunner \&Suddarth. (2006). Brunner

\&Suddarth Surgery Volume 1.

Jakarta: Egc.

Efendi, S. \&. (2013). Characteristics of Inguinal Hernia Sufferers Inpatient at Anutapura Palu Hospital in 2012, vol 1 no 1. Retrieved from www.jurnal kesehatan tadaluko

Fatmah. (2010). Elderly Nutrition. Jakarta: Erland.

Potter, Patricia A \& Perry, A. G. (2007).

Fundamental Nursing.Issue 4. Jakarta: Egc.

Tamer, S. \&Noorkasiani. (2009). Elderly Health With A Nursing Care Approach. Jakarta: salemba Medika.

Vera Anik, A. (2014). http//journal Unnes.ac.id/sju/index.php. Retrieved from http//journal Unnes.ac.id/sju/index.php

Corwin, E. J. (2009). Patofisiologi. Jakarta: EGC.

Riskesdas. (2013). Riset Kesehatan Dasar.

Hasil Riskesdas 2013. 